\title{
Innate immunity and disorders of the female reproductive tract
}

\author{
Andrew W Horne, Sarah J Stock and Anne E King \\ The Queen's Medical Research Institute, Reproductive and Developmental Sciences, Centre for Reproductive Biology, \\ University of Edinburgh, 47 Little France Crescent, Edinburgh EH16 4TJ, UK
}

Correspondence should be addressed to A E King; Email: anne.king@ed.ac.uk

\begin{abstract}
Sexually transmitted infections, and their associated sequelae, such as tubal infertility, ectopic pregnancy and preterm labour, are a major worldwide health problem. Chlamydia trachomatis infection is thought to be the leading global cause of tubal infertility and tubal ectopic pregnancy. Preterm birth occurs in around $10 \%$ of all deliveries, and nearly $30 \%$ of preterm deliveries are associated with intrauterine infection. The mucosal innate immune system of the female reproductive tract has evolved to eliminate such sexually transmitted pathogens whilst maintaining its ability to accommodate specialized physiological functions that include menstruation, fertilization, implantation, pregnancy and parturition. The aim of this review was to describe the role and distribution of key mediators of the innate immune system, the natural antimicrobial peptides (secretory leukocyte protease inhibitor, elafin and the defensins) and the pattern recognition toll-like receptors in the normal female reproductive tract and in the context of these pathological processes.
\end{abstract}

Reproduction (2008) 135 739-749

\section{Introduction}

The innate immune system incorporates more rapid and primitive responses to infection than the adaptive immune system, such as surface defences, cytokine elaboration, complement activation and phagocytic responses (Janeway \& Medzhitov 2002, Tosi 2005). Together, these effect pathogen elimination and are responsible for the stereotypical inflammatory response. The natural antimicrobial peptides (NAPs) and pattern recognition toll-like receptors (TLRs) are key mediators of the innate immune system (Wira et al. 2005). NAPs are released at epithelial surfaces and disrupt the membranes of many microbial pathogens (Ganz 2004). TLRs at mucosal surfaces recognize a range of microbial molecular patterns and generate intra-cellular signals through nuclear factor- $\kappa \mathrm{B}$ (NFKB) dependent (and independent) pathways to induce chemokine and cytokine expression that activate a range of host responses (Zarember \& Godowski 2002). A summary of the cellular origin, target cell lineages and function of each family of molecules is shown in Fig. 1. The role of macrophages, dendritic, myeloid, natural killer cells and neutrophils in the innate immune system are outwith the scope of this review and have been recently discussed in detail elsewhere (Wira et al. 2005). Similarly, this review focuses specifically on data from human studies, except where individual animal work was thought to be especially relevant.
The mucosal innate immune system of the female reproductive tract is uniquely adapted to facilitate specialized physiological functions that include menstruation, fertilization, implantation, pregnancy and parturition, whilst eliminating threatening sexually transmitted and environmental pathogens. Sexually transmitted infections (STIs), and their associated problems, are a major worldwide health problem (see Fig. 2). World Health Organisation figures estimated that 89 million new cases of genital Chlamydia trachomatis infections occurred in 1995, highlighting the worldwide prevalence of infections and the economic burden on healthcare delivery (Beagley \& Timms 2000). C. trachomatis infection is thought to be the leading global cause of tubal infertility and tubal ectopic pregnancy (Faro 1991, Farquhar 2005). One in six couples suffer from infertility, with tubal disease being the direct cause in over 25\% of cases (Mardh 2004). Tubal ectopic pregnancy occurs in 1 in 80 pregnancies and remains a common cause of morbidity in early pregnancy and occasional mortality (Tay et al. 2000). Preterm birth occurs in around $10 \%$ of all deliveries, and nearly $30 \%$ of preterm deliveries are associated with intrauterine infection (Ananth \& Vintzileos 2006, Romero et al. 2007).

Innate immune system competence is of critical importance in preventing microbial penetration. In this context, it is important to consider the differences in the microenvironments of the 'sterile' upper and 'non-sterile' 


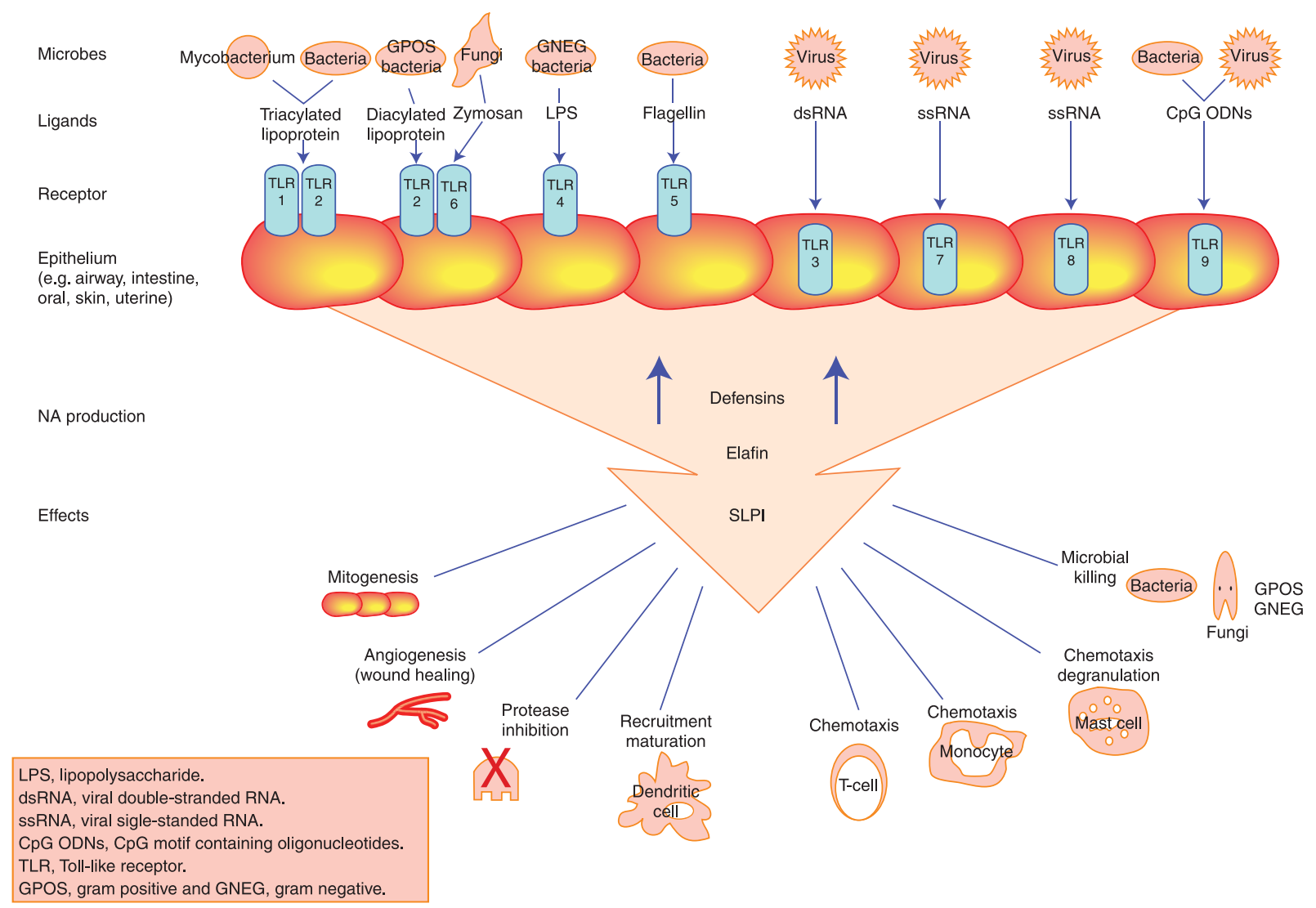

Figure 1 Summary illustrating the cellular origin, target cell lineages and function of the natural antimicrobial peptides, defensins and toll-like receptors.

lower female reproductive tract (see Fig. 3). Each of these distinct microbial milieu are likely to have a compartmentalized innate immune response that shows temporal changes in their expression of innate immune molecules in response to oestrogen and progesterone (Sonnex 1998, Pioli et al. 2004). The vagina and ectocervix harbour a variety of commensal bacteria and are subject to secondary contamination as a result of their proximity to the rectum (Quayle 2002). Despite this constant exposure to microbes, infections are relatively uncommon suggesting effective containment or efficient elimination of pathogens. The endocervix represents a transitional area and it is the epithelia that are most frequently infected with $C$. trachomatis (Quayle 2002). Infection of the endometrium and Fallopian tube can result if pathogens breach the cervical barrier resulting in adverse reproductive consequences (Wiesenfeld et al. 2002). During pregnancy, the cervical mucus plug and the placenta and fetal membranes also contribute to the innate immune response, maintaining the sterility of the uterine cavity and protecting the developing fetus.

Improved understanding of innate immunity within the female reproductive tract will inform on interventive strategies to protect against disease caused by pathogens

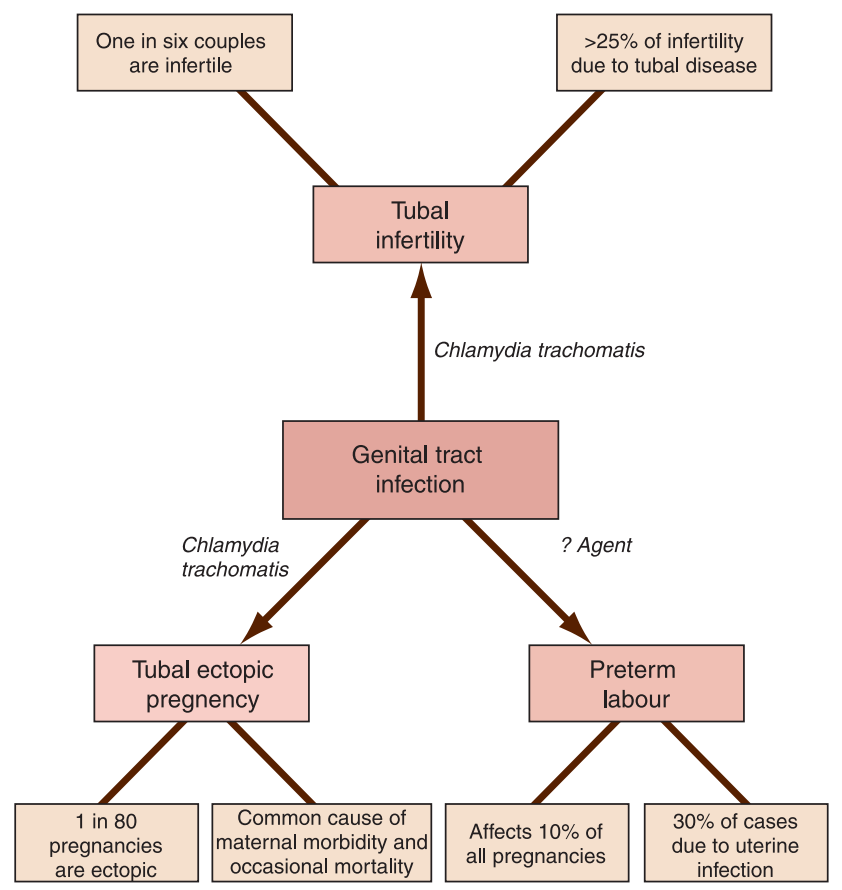

Figure 2 The burden of genital tract infection on reproductive health. 


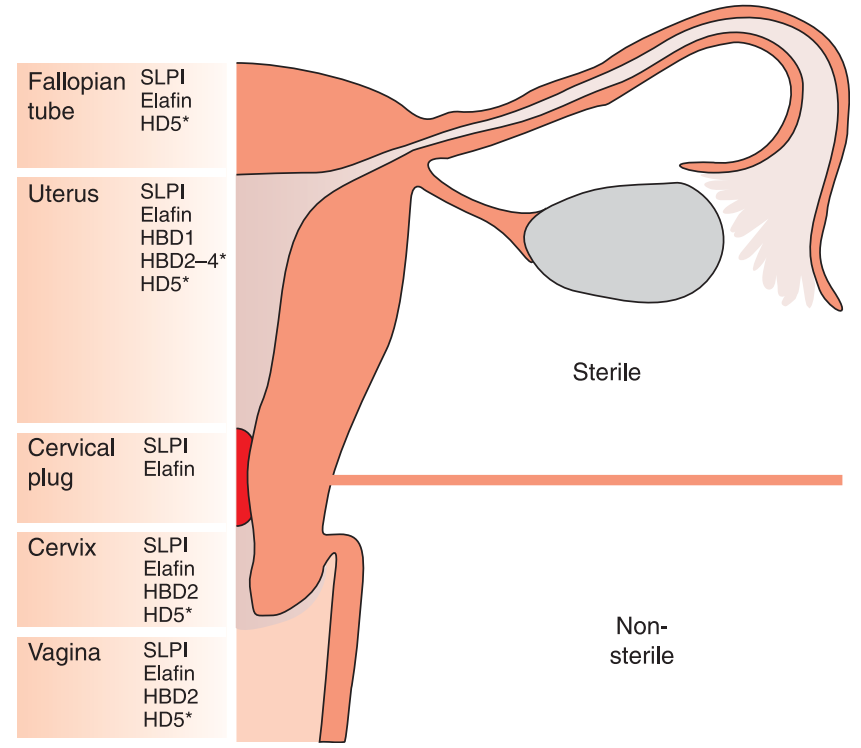

Figure 3 Expression of SLPI, elafin and defensins in the non-pregnant female reproductive tract. *Protein expression has not been reported. such as $C$. trachomatis (which may help reduce the incidence of infection-related tubal infertility and tubal ectopic pregnancy) and will inform on the clinical management of intrauterine infection during pregnancy.

\section{Natural antimicrobial peptides (NAPs)}

Whey acidic protein motif containing proteins: secretory leukocyte protease inhibitor (SLPI) and elafin

Uncontrolled inflammation can result in tissue destruction, in part mediated by proteases (Dallegri \& Ottonello 1997). Anti-proteases, such as SLPI and elafin, counteract the actions of proteases and help prevent resultant damage to host tissues from an over-exuberant response (Sallenave et al. 1994, Schalkwijk et al. 1999, Sallenave 2000). SLPI inhibits a number of proteases, including neutrophil elastase, trypsin and cathepsin G, whilst elafin appears to be restricted to regulating neutrophil elastase and proteinase 3 (Thompson \& Ohlsson 1986, Sallenave \& Ryle 1991, Wiedow et al. 1991). Both proteins are also potent NAPs, with activity against

Table 1 Natural antimicrobial expression in the female reproductive tract (the menstrual cycle phase showing peak expression of each natural antimicrobial is detailed where this has been reported).

\begin{tabular}{|c|c|c|c|c|c|c|}
\hline \multirow[b]{2}{*}{ Expression site } & \multicolumn{6}{|c|}{ Natural antimicrobial } \\
\hline & HBD1 & HBD2 & HBD3 & HBD4 & SLPI & Elafin \\
\hline \multicolumn{7}{|c|}{ Non-pregnant } \\
\hline Fallopian tube & $\begin{array}{l}\text { mRNA (Valore } \\
\text { et al. 1998) }\end{array}$ & Not reported & Not reported & Not reported & $\begin{array}{l}\text { mRNA and protein } \\
\text { (AW Horne, unpub- } \\
\text { lished observations, } \\
\text { Ota et al. 2002) }\end{array}$ & $\begin{array}{l}\text { mRNA and protein } \\
\text { (AW Horne, unpub- } \\
\text { lished observations) }\end{array}$ \\
\hline Endometrium & $\begin{array}{l}\text { mRNA highest in } \\
\text { secretory phase } \\
\text { (Fleming et al. } \\
\text { 2003) }\end{array}$ & $\begin{array}{l}\text { mRNA highest at } \\
\text { menstruation } \\
\text { (Fleming et al. } \\
\text { 2003) }\end{array}$ & $\begin{array}{l}\text { mRNA highest in } \\
\text { secretory phase } \\
\text { (King et al. 2003b) }\end{array}$ & $\begin{array}{l}\text { mRNA highest in } \\
\text { proliferative } \\
\text { phase (King } \\
\text { et al. 2003b) }\end{array}$ & $\begin{array}{l}\text { mRNA and protein } \\
\text { highest in secretory } \\
\text { phase (King et al. 2000) }\end{array}$ & $\begin{array}{l}\text { mRNA and protein } \\
\text { highest at } \\
\text { menstruation } \\
\text { (King et al. 2003a) }\end{array}$ \\
\hline Cervix & $\begin{array}{l}\text { mRNA (Valore } \\
\text { et al. 1998) }\end{array}$ & Not reported & Not reported & Not reported & $\begin{array}{l}\text { Protein (Moriyama et al. } \\
\text { 1999) }\end{array}$ & $\begin{array}{l}\text { Protein (Pfundt et al. } \\
\text { 1996) }\end{array}$ \\
\hline Vagina & $\begin{array}{l}\text { mRNA (Valore } \\
\text { et al. 1998, } \\
\text { Narvekar et al. } \\
\text { 2007) }\end{array}$ & $\begin{array}{l}\text { mRNA (Narvekar, } \\
\text { et al. 2007) }\end{array}$ & $\begin{array}{l}\text { mRNA (Narvekar } \\
\text { et al. 2007) }\end{array}$ & Not reported & $\begin{array}{l}\text { Protein - cell line } \\
\text { (Fichorova \& Anderson } \\
\text { 1999, Valore et al. } \\
\text { 2006) }\end{array}$ & $\begin{array}{l}\text { Protein (Pfundt et al. } \\
\text { 1996) mRNA } \\
\text { (Narvekar, et al. } \\
\text { 2007) }\end{array}$ \\
\hline \multicolumn{7}{|c|}{ 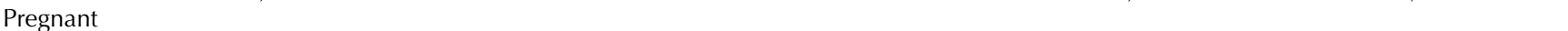 } \\
\hline Amnion & $\begin{array}{l}\text { mRNA and } \\
\text { protein (King } \\
\text { et al. 2007) }\end{array}$ & $\begin{array}{l}\text { mRNA and } \\
\text { protein (King } \\
\text { et al. 2007, } \\
\text { Stock et al. 2007) }\end{array}$ & $\begin{array}{l}\text { mRNA and } \\
\text { protein (King } \\
\text { et al. 2007) }\end{array}$ & Not reported & $\begin{array}{l}\text { Protein (Zhang et al. } \\
\text { 2001) }\end{array}$ & $\begin{array}{l}\text { mRNA and } \\
\text { protein (King et al. } \\
\text { 2007) }\end{array}$ \\
\hline Chorion & $\begin{array}{l}\text { mRNA and } \\
\text { protein (King } \\
\text { et al. 2007) }\end{array}$ & $\begin{array}{l}\text { mRNA and } \\
\text { protein (King } \\
\text { et al. 2007) }\end{array}$ & $\begin{array}{l}\text { mRNA and } \\
\text { protein (King } \\
\text { et al. 2007) }\end{array}$ & Not reported & $\begin{array}{l}\text { Mainly negative } \\
\text { (Denison et al. 1999) }\end{array}$ & $\begin{array}{l}\text { mRNA and } \\
\text { protein (King et al. } \\
2007)\end{array}$ \\
\hline Placenta & $\begin{array}{l}\text { mRNA and } \\
\text { protein (King } \\
\text { et al. 2007) }\end{array}$ & $\begin{array}{l}\text { mRNA and } \\
\text { protein (King } \\
\text { et al. 2007) }\end{array}$ & $\begin{array}{l}\text { mRNA and } \\
\text { protein (King } \\
\text { et al. 2007) }\end{array}$ & Not reported & $\begin{array}{l}\text { Mainly negative } \\
\text { (Denison et al. 1999) }\end{array}$ & $\begin{array}{l}\text { mRNA and } \\
\text { protein (King et al. } \\
2007)\end{array}$ \\
\hline Decidua & $\begin{array}{l}\text { mRNA and } \\
\text { protein (King } \\
\text { et al. 2007) }\end{array}$ & $\begin{array}{l}\text { mRNA and } \\
\text { protein (King } \\
\text { et al. 2007) }\end{array}$ & $\begin{array}{l}\text { mRNA and } \\
\text { protein (King } \\
\text { et al. 2007) }\end{array}$ & Not reported & $\begin{array}{l}\text { mRNA and protein } \\
\text { (Denison et al. 1999, } \\
\text { King et al. 2000) }\end{array}$ & $\begin{array}{l}\text { mRNA and } \\
\text { protein (King et al. } \\
2007)\end{array}$ \\
\hline $\begin{array}{l}\text { Cervical } \\
\text { mucus plug }\end{array}$ & $\begin{array}{l}\text { Protein (Hein } \\
\text { et al. 2002) }\end{array}$ & Not reported & Not reported & Not reported & $\begin{array}{l}\text { Protein (Helmig et al. } \\
\text { 1995, Hein et al. 2002) }\end{array}$ & Not reported \\
\hline $\begin{array}{l}\text { Vaginal } \\
\text { secretions }\end{array}$ & Not reported & $\begin{array}{l}\text { Protein (SJ Stock, } \\
\text { unpublished } \\
\text { observations) }\end{array}$ & Not reported & Not reported & $\begin{array}{l}\text { Protein (SJ Stock, } \\
\text { unpublished } \\
\text { observations) }\end{array}$ & $\begin{array}{l}\text { Protein (SJ Stock, } \\
\text { unpublished } \\
\text { observations) }\end{array}$ \\
\hline
\end{tabular}


gram-positive and gram-negative organisms (Simpson et al. 1999).

SLPI and elafin are expressed throughout the female genital tract (King et al. 2000, 2003 c; see Table 1). SLPI and elafin expression has been demonstrated in the vagina (Draper et al.2000) and cervix, with high concentrations of SLPI demonstrated in the cervical mucus (Helmig et al. 1995, Pfundt et al. 1996). We have shown that endocervical and vaginal cell lines express both SLPI and elafin, and that expression in endocervical cells is increased by treatment with the bacterial wall product lipopolysaccharide (SJ Stock, unpublished observations). Neutrophils within the human endometrium area particularly rich source of elafin during menstruation (see Fig. 4), whereas the endometrial epithelium expresses SLPI during the progesterone-dominant secretory phase of the cycle (King et al. 2000, 2003c). In vitro studies of polarized endometrial epithelial cells have shown that the presence of an anti-SLPI antibody reduces the antibacterial activity of secretions from the apical surface of these cells (Fahey \& Wira 2002). These functional data suggest that SLPI is involved in the endometrial innate immune response at least in vitro. In common with the rest of the female reproductive tract, the Fallopian tube morphology undergoes cyclical changes under the influence of oestrogen and progesterone (Sulz et al. 1998), and while SLPI and elafin expression have been localized to the Fallopian tube epithelium (Ota et al. 2002, Horne et al. unpublished data) their temporal expression profiles have not been detailed.

SLPI and elafin are also present during pregnancy. SLPI is present in extremely high concentrations in the cervical mucus plug, a key barrier to upper genital tract infection during pregnancy (Hein et al. 2002) and both SLPI and elafin are present in the vaginal secretions in pregnancy (Stock et al. unpublished). SLPI is present in first trimester decidua (King et al. 2000) and the main

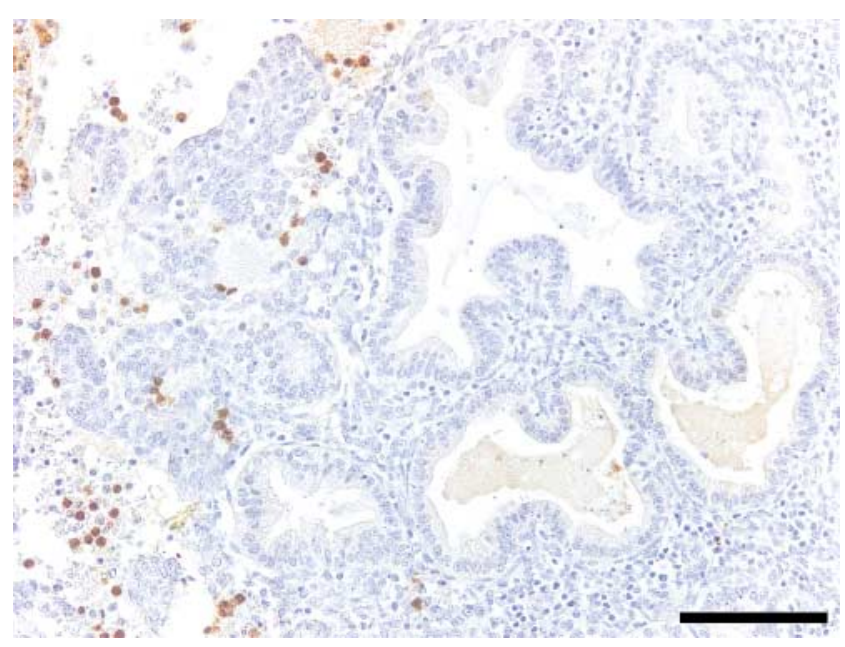

Figure 4 Immunohistochemical localization of elafin in endometrium from the menstrual phase. Elafin is present in endometrial neutrophils (brown staining). Scale bar $=100 \mu \mathrm{m}$. sites of expression within the uterus at term pregnancy are the amnion epithelium and decidua (Denison et al. 1999). SLPI concentrations in amniotic fluid are increased in late gestation and particularly with the onset of labour (Denison et al. 1999). Elafin is localized to the amnion epithelium, decidua, chorion and placental trophoblast (King et al. 2007). The presence of SLPI and elafin at several uterine sites during gestation indicates that they may have an important natural antimicrobial role but also that their anti-protease and anti-inflammatory activity may be involved in preventing excessive inflammation and tissue remodelling during pregnancy.

SLPI and elafin demonstrate a variety of antiinflammatory effects in a number of other tissues, which cannot be solely attributed to their anti-proteinase or anti-bacterial activities. In an animal model of chemically induced lung fibrosis, administration of SLPI decreases tissue damage, and even a truncated form that lacks the anti-elastase domain exerts this effect (Mitsuhashi et al. 1996). SLPI also decreases cortical damage after ischaemic-induced stroke in rats (Wang et al. 2003). Forced expression of elafin in animal models modulates the systemic and pulmonary response to lipopolysaccharide (LPS; Sallenave et al. 2003) and reduces inflammation associated with myocardial infarction (Ohta et al. 2004). In humans, SLPI and elafin induction appear attenuated in Crohn's disease, characterized by inflammation affecting the full thickness of intestinal wall, when compared with ulcerative colitis, which is an inflammatory condition only involving the mucosa (Schmid et al. 2007). Some of the antiinflammatory effects of the anti-leukoproteinases may involve inhibition of NFKB. In vitro, overexpression of SLPI suppresses NFKB activation (Jin et al. 1997, Sano et al. 2003, Henriksen et al. 2004). It can prevent proteosome-dependent І $\kappa \mathrm{B} \beta$ degradation (Lentsch et al. 1999) and also directly bind to NFKB consensus sites on DNA, inhibiting transcription (Taggart et al. 2005). Wound healing and tissue remodelling are other processes involving the anti-leukoproteinases. SLPI and elafin are produced in response to cutaneous injury (van Bergen et al. 1996, Wingens et al. 1998) and SLPI null mice show impaired cutaneous wound healing and increased inflammation and elastase activity (Ashcroft et al. 2000, Angelov et al. 2004). SLPI can also modulate production of matrix metalloproteinases from monocytes by inhibiting enzymes involved in $\mathrm{PGE}_{2}$ (prostaglandin $E_{2}$ ) synthesis (Zhang et al. 1997).

\section{Defensins}

Leukocytes and epithelial cells are the main sources of human defensins (Klotman \& Chang 2006). Human $\beta$-defensins (HBD) $1-4$ and $\alpha$-defensin (human defensin 5, HD5) have all been reported to be expressed in the endometrial epithelium, each with their own unique 
temporal expression profile (Svinarich et al. 1997, Quayle et al. 1998, Valore et al. 1998, Fleming et al. 2003, King et al. 2003a,b). HBD1, HBD3 and HD5 are expressed at highest levels during the secretory phase (Quayle et al. 1998, Fleming et al. 2003, King et al. 2003b; see Table 1). By contrast, HBD2 mRNA expression shows a dramatic peak during menstruation while HBD4 is expressed mainly in the proliferative phase (Fleming et al. 2003, King et al. 2003b). The functional implications of these different patterns of expression have not been determined and may relate to differences in antimicrobial activity of members of the defensin family or to their other activities such as regulation of leukocyte chemotaxis. HD5 has also been demonstrated in the vagina, cervix and Fallopian tube (Quayle et al. 1998). HBD2 is also present in cervicovaginal secretions and is expressed by a vaginal keratinocyte cell line in vitro (SJ Stock, unpublished observations). HBD1-3 are widely expressed in the pregnant uterus with expression in the amnion, decidua, chorion and placental trophoblast (King et al. 2007, Stock et al. 2007). Their presence at key sites suggests that they are likely to be involved in the innate immune response during pregnancy and may act to prevent uterine infection (see Table 1).

\section{Toll-like receptors (TLRs)}

TLRs 1-10 are expressed in the female reproductive tract (Darville et al. 2003, Pioli et al. 2004, Aflatoonian et al. 2007). Vaginal epithelial cell lines have been shown to express TLR1-3, TLR5 and TLR6, and primary endocervical epithelial cells have been shown to express TLR1-3 and TLR6 (Fichorova et al. 2002). Endometrial epithelial cell lines, primary endometrial epithelial cells and primary decidual cell cultures express TLR1-9, indicating the potential to respond to a wide range of pathogens (Schaefer et al. 2004, 2005, Krikun et al. 2007). TLRs are present in both endometrial epithelial and stromal cells (Aflatoonian et al. 2007, Hirata et al. 2007) and have also been reported in uterine NK cells, an endometrial cell with a key role in implantation and early pregnancy (Eriksson et al. 2006).

The TLRs are differentially expressed in each individual reproductive tract tissue and also show cycledependent expression in the endometrium. For example, TLR2 and TLR4 show higher expression in the Fallopian tube and endometrium compared with that in the cervix (Pioli et al. 2004). Studies detailing cycle-dependent expression in endometrium are contradictory with one study suggesting that TLR2-4 and TLR9 mRNA expression is higher during the perimenstrual phase (Hirata et al. 2007), while another shows peak expression of TLR2-6, TLR9 and TLR10 mRNA in the secretory phase (Aflatoonian et al. 2007). However, there are differences in the cycle phases compared in these studies and also in the way that menstrual cycle phase was confirmed.
TLRs have been shown to be functional in cell types from throughout the reproductive tract in in vitro experiments. Endometrial, cervical and Fallopian tube epithelial cells have both been shown to respond to the TLR3 ligand, poly I:C, with increased cytokine output (Lesmeister et al. 2005, Andersen et al. 2006, Ghosh et al. 2008, Nasu et al. 2007). Fallopian tube fibroblasts and endometrial epithelial and stromal cells have been shown to increase inflammatory mediator output in response to LPS (lipopolysaccharide), a TLR4 ligand (Hirata et al. 2005, Itoh et al. 2006). These in vitro data suggest that TLRs on reproductive tract cells will be capable of responding to pathogen products in vivo.

TLRs are also present in the pregnant uterus. Several studies have examined TLR expression both in the first trimester and in late pregnancy. TLR2 and TLR4 are widely reported to be present on trophoblast cells (Holmlund et al. 2002, Abrahams et al. 2004, Kumazaki et al. 2004, Beijar et al. 2006, Ma et al. 2007). The related, intracellular innate immune receptors nucleotide oligomerization domain (NOD) 1 and 2 are also present in the first trimester trophoblast (Costello et al. 2007). In vitro studies with the first trimester trophoblast have shown TLR3 and TLR4 to respond to their ligands by increasing cytokine and chemokine output and increasing chemotaxis of monocytes and neutrophils (Abrahams et al. 2004, 2005, 2006). Similar studies have shown TLRs on syncytiotrophoblast and in villous explants from term pregnancies to signal responses to ligand binding (Holmlund et al. 2002, Ma et al. 2007). These studies suggest that the trophoblast is capable of mounting an innate immune response and may also initiate activation of the adaptive immune response.

\section{Disorders of the female reproductive tract}

\section{Sexually transmitted infection}

The potential role of natural antimicrobials in preventing STI is unclear and there are very few studies investigating the activity of natural antimicrobials against genital tract pathogens (see Table 2). We have shown that bacterial vaginosis, a condition associated with increased transmission of STIs, is associated with low levels of both elafin and SLPI in cervicovaginal secretions (S) Stock, unpublished observations). In addition, low levels of SLPI in vaginal secretions are associated with the presence of various lower reproductive tract infections, including Chlamydia (Draper et al. 2000). This study suggested that these low levels of SLPI may result from degradation by pathogens or reduced expression as a consequence of damage to mucosal surfaces due to infection. An alternative possibility is that defective natural antimicrobial production or function may predispose to genital tract infection. This remains to be investigated. 
Table 2 The role of natural antimicrobials and pattern recognition receptors in disorders of the female reproductive tract.

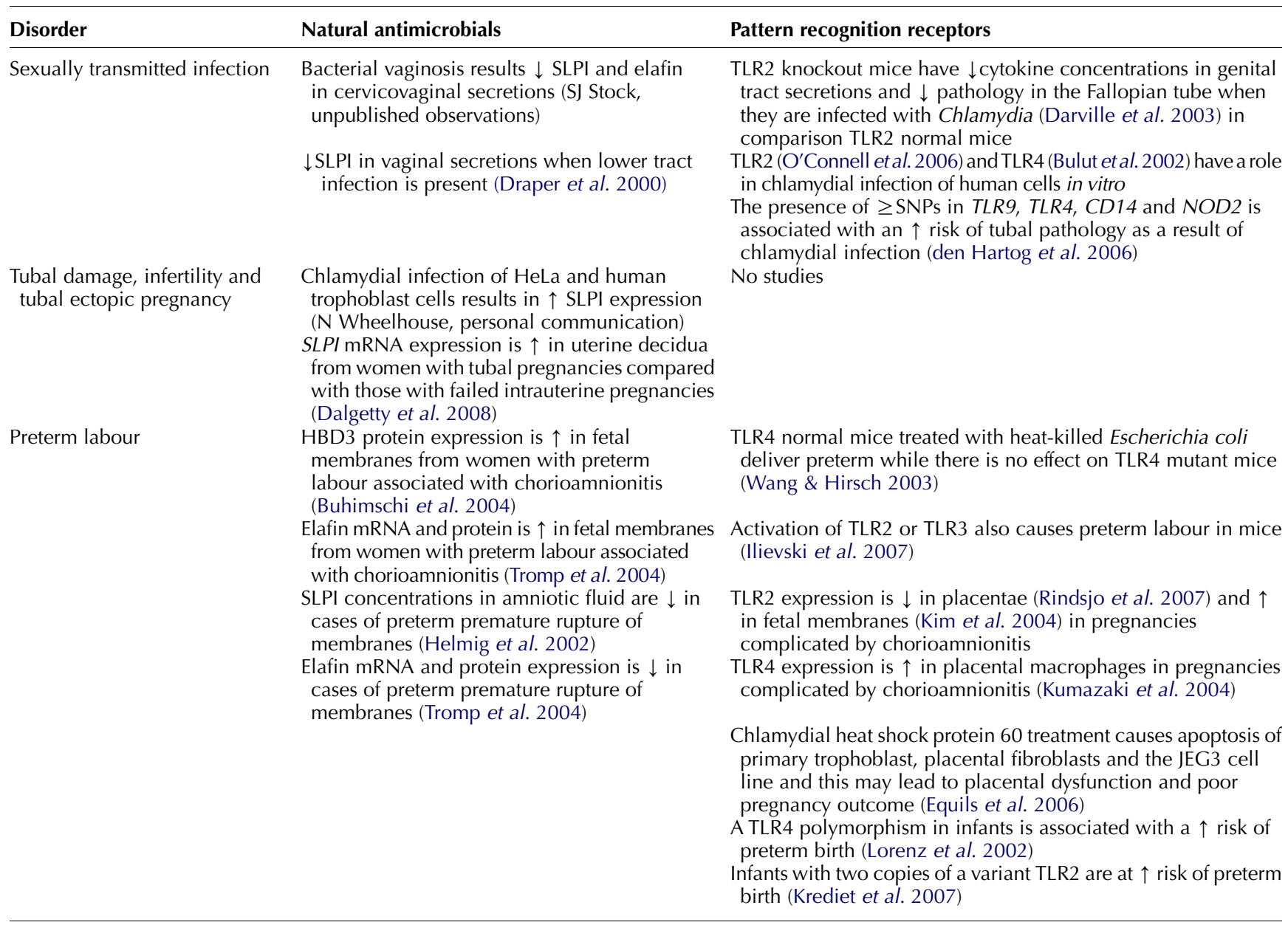

There are data to suggest that TLRs may be involved in the pathology of STIs (see Table 2), particularly $C$. trachomatis and Neisseria gonorrhoeae. Infection of TLR2 knockout mice with Chlamydia muridarum (previously classified as the mouse biovar of $C$. trachomatis) results in reduced levels of the cytokines, tumour necrosis factor $\alpha$ and MIP2 (macrophage inflammatory protein), in genital tract secretions and reduced chronic pathology in the Fallopian tube relative to normal mice, although the progression of infection does not differ (Darville et al. 2003). This suggests that, at least in the mouse, TLR2 plays a central role in Fallopian tube pathology as a result of chlamydial infection. Mice deficient in TLR4 did not show changes relative to the wild type. Studies in mice also suggest that NOD1 does not play a major role in the genital tract response to chlamydial infection. While the presence of a dominant negative mutant of NOD1 partially inhibited NFKB activation as a result of chlamydial infection of the cervical epithelial HeLa cell line, proinflammatory mediator expression in the genital tracts of NOD1deficient mice after chlamydial infection was comparable with that in wild-type mice (Welter-Stahl et al. 2006). However, these data may not be representative of infection with $C$. trachomatis as the pathology of infection has been reported to differ between $C$. muridarum and C. trachomatis (Morre et al. 2000).

There are few studies examining the role of TLRs in the infection of human cells with $C$. trachomatis and these have yielded conflicting information depending on the cell type examined. However, there is evidence to suggest that TLR2 and TLR4 may both be involved in the response to Chlamydia. O'Connell et al. (2006) have reported that TLR2 is recruited to intracellular Chlamydiae in HEK293 cells transfected with TLR2 and that TLR2 is required for cellular activation (determined by IL-8 measurement) during infection. In human microvascular cells, chlamydial heat shock protein 60 (HSP60) acts via TLR4 to activate NFKB and increase IL-8 secretion (Bulut et al. 2002).

The role of TLRs and NODs expressed by cells of the female reproductive tract (e.g. Fallopian tube epithelium) in the response to chlamydial infection, or any $\mathrm{STI}$, remains poorly understood. However, the 
aforementioned differences in the expression pattern of the TLRs in individual reproductive tract microenvironments suggest they may contribute, at least in part, to a compartmentalized immune response towards pathogen invasion (Pioli et al. 2004). Furthermore, a recent study examining single nucleotide polymorphisms in TLR9, TLR4, CD14 and NOD2 in women with chlamydial infections indicated that women with SNPs in two or more of these genes have a trend towards an increased risk of tubal pathology (den Hartog et al. 2006) suggesting that pattern recognition receptors are involved in the progression of the infection.

\section{Tubal damage, infertility and tubal ectopic pregnancy}

Although it has been suggested that chlamydial infection is one of the major causes of tubal damage (Odland et al. 1993), the innate immunopathogenic events that lead to infertility and tubal ectopic pregnancy following infection are unclear (see Table 2). In vitro studies have demonstrated that Chlamydia induces expression of SLPI in HeLa and a human trophoblast cell line ( $\mathrm{N}$ Wheelhouse, personal communication). It is possible that Chlamydia acts via NFKB by way of the above signalling cascade, and that persistent, or repeated, infection causes atypical expression of SLPI in the uterus and Fallopian tube leading to tubal damage, and/or blockage, or to a susceptibility to tubal implantation. To our knowledge, there have been no studies performed examining the expression pattern of NAPs or TLRs in these pathologies.

With tubal ectopic pregnancy, direct comparison of the expression of factors important for innate immunity between tubal and intrauterine sites is difficult due to the anatomical differences of the two implantation locations. However, similar to the endometrial response to an intrauterine pregnancy, with a tubal gestation, there is a decidual reaction in the uterine cavity but not usually in the Fallopian tube (Stock 1991). The uterine decidua contains innate immune leukocytes, such as CD56+ uterine natural killer cells, macrophages and mast cells (Bulmer et al. 1988, King \& Loke 1991, Clark et al. 1994, Hunt 1994, Marx et al. 1999). We therefore compared SLPI and elafin expression in the uterine decidua of women with ongoing intrauterine (women undergoing surgical termination of pregnancy), failed intrauterine (women with miscarriage) and tubal gestations and demonstrated that SLPI (but not elafin) mRNA expression was significantly higher in the uterine decidua of women with a tubal compared with a failed intrauterine gestation (miscarriage; Dalgetty et al. 2008). If the uterine environment truly reflects that of the Fallopian tube, the abnormal expression of SLPI in the uterine decidua may simply mirror the biological changes occurring in the Fallopian tube due to extra-uterine implantation. Alternatively, the abnormal expression of
SLPI may predispose to, rather than be a consequence of, tubal pregnancy.

\section{Preterm birth}

There is evidence to suggest that expression of natural antimicrobials is altered in preterm labour, particularly in cases of chorioamnionitis (see Table 2). HBD3 protein (Buhimschi et al. 2004) and elafin mRNA and protein expression (Tromp et al. 2004) have both been reported to increase in the fetal membranes of pregnancies complicated with chorioamnionitis suggesting that these natural antimicrobials are upregulated as a result of infection. In addition, amniotic fluid concentrations of SLPI (Helmig et al. 2002) and mRNA and protein expression of elafin in fetal membranes (Tromp et al. 2004) are reduced in cases of preterm premature rupture of membranes. This reduced expression may result in decreased anti-protease activity promoting a shift in favour of protease-mediated degradation of membranes. Their reduced expression may, however, also reduce antimicrobial protection in the uterus, allowing the establishment of detrimental infections. It should be noted that the studies detailed above do not address whether the changes described are a cause or effect of the pathology and there are no functional data showing a role for natural antimicrobials in preterm labour.

Studies in mice suggest that activation of TLRs results in preterm labour. Administration of heat-killed Escherichia coli to TLR-normal pregnant mice results in preterm labour, while identical treatment of TLR4mutant mice has a reduced effect. In this study, TLR4 stimulation reduced prostaglandin dehydrogenase expression in fetal membranes and myometrium resulting in increased local concentrations of prostaglandins; mediators with a well-established role in the onset of labour (Wang \& Hirsch 2003). Preterm delivery also occurs in mice upon activation of TLR2 or TLR3 (Ilievski et al. 2007) with TLR3 activation resulting in increased levels of CCL5 and IFN $\gamma$ in uterine tissues. Zhang et al. (2007) have reported pregnancy failure and abnormal uterine spiral artery development in mice as a result of administration of the TLR3 agonist, poly I:C, earlier in gestation. These studies suggest that the presence of TLR ligands in the uterus stimulate local inflammatory pathways resulting in preterm labour.

Studies in human pregnancies also suggest that TLRs may be involved in the onset of preterm labour associated with infection. It has been reported that TLR2 and TLR4 protein expression is altered in pregnancies complicated with chorioamnionitis (inflammation between the amnion and the chorion). TLR2 expression is reported to be reduced in placentae affected by chorioamnionitis (Rindsjo et al. 2007), while it is increased in chorioamnion (Kim et al. 2004). TLR4 expression in placental macrophages (Hofbauer cells) is also reported to increase in preterm delivery 
complicated with chorioamnionitis (Kumazaki et al. 2004). While these studies suggest that TLR expression changes with chorioamnionitis, it remains unclear whether this is a cause or effect of inflammation and/or parturition. Additionally, changes in expression may not be reflected in functional activity of the TLRs although some studies have suggested that there may be an association between TLR function and pregnancy failure or preterm labour. The chlamydial HSP60 has been shown to cause apoptosis of primary first trimester trophoblast cells, placental fibroblasts and the JEG3 trophoblast cell line via TLR4 (Equils et al. 2006). It has been suggested that TLR4 activity may cause placental apoptosis and possibly compromise a pregnancy in women with chlamydial infection. In addition, Lorenz et al. (2002) have reported that when an Asp299Gly polymorphism is present in the TLR4 gene of infants they have a higher risk of preterm birth. This polymorphism causes impaired receptor function suggesting that a reduced response to gram-negative bacteria increases the likelihood of infection and subsequent preterm labour. It has also been reported that infants carrying two copies of a variant TLR2 gene are at increased risk of premature delivery (Krediet et al. 2007).

\section{Conclusion}

Infection and inflammation can have devastating consequences to fertility and pregnancy. To date, most interventions directed at preventing and treating such infections have focused on pathogen elimination through the use of antibiotics. Unfortunately, these strategies have been disappointing in eradicating such infections, or decreasing the burden of related complications, such as tubal infertility, ectopic pregnancy and preterm birth.

The study of the innate immune response has highlighted the importance of host-related factors in the response to infectious agents. Genetic variation in innate immunity can explain individual differences in responses to infection. A suboptimal innate immune response may result in a permissive environment for pathogen colonization, whereas an over-exuberant response will cause excessive inflammation and tissue damage. This may be why a 'one-size fits all' approach has been hitherto unsuccessful and modulation of the host response to infection is an attractive alternative or adjuvant approach to antibiotic therapies in treatment of genital tract infections. TLR agonists and antagonists are currently under clinical development for the treatment of cancer, allergies and as vaccines and vaccine adjuvants (Kanzler et al. 2007) raising the possibility that in the future interventions may be aimed at modulating the innate immune response in the reproductive tract. Further research into the innate immune response may elucidate pathological mechanisms underlying infectious morbidities such as tubal infertility and preterm labour, but as yet few studies have examined the functional effects of innate immune components such as NAPs and TLRs in the reproductive tract. While existing SLPI (Ashcroft et al. 2000) and TLRnull (Sugawara et al. 2003, Andersen-Nissen et al. 2007) mutant mouse models show impaired wound healing and altered responses to infection, they have provided little information relating directly to the reproductive tract. In addition, fundamental differences in key physiological reproductive processes, such as implantation and placentation, exist between mouse and human limiting the relevance of these rodent models.

It is anticipated that a greater understanding of the function of the innate immune system in the reproductive tract and the development of TLR agonists and antagonists for clinical use may lead to advances in the management of clinically important conditions, such as tubal infertility, ectopic pregnancy and preterm labour.

\section{Acknowledgements}

Dr Andrew Horne is supported by a Chief Scientist's Office Project Grant (Ref. CBZ/4/513). Dr Sarah Stock is supported by the Jennifer Brown Laboratory. Dr Anne King is also supported by the Chief Scientist's Office Project Grant and a personal research fellowship from the Caledonian Research Foundation. The authors wish to thank Professor Hilary Critchley and Dr Gary Entrican for proofreading the manuscript, and Ronnie Grant and Ted Pinner for the illustrations. The authors declare that there is no conflict of interest that would prejudice the impartiality of this scientific work.

\section{References}

Abrahams VM, Bole-Aldo P, Kim YM, Straszewski-Chavez SL, Chaiworapongsa T, Romero R \& Mor G 2004 Divergent trophoblast responses to bacterial products mediated by TLRs. Journal of Immunology 173 4286-4296.

Abrahams VM, Visintin I, Aldo PB, Guller S, Romero R \& Mor G 2005 A role for TLRs in the regulation of immune cell migration by first trimester trophoblast cells. Journal of Immunology 175 8096-8104.

Abrahams VM, Schaefer TM, Fahey JV, Visintin I, Wright JA, Aldo PB, Romero R, Wira CR \& Mor G 2006 Expression and secretion of antiviral factors by trophoblast cells following stimulation by the TLR-3 agonist, poly(I:C). Human Reproduction 21 2432-2439.

Aflatoonian R, Tuckerman E, Elliott SL, Bruce C, Aflatoonian A, Li TC \& Fazeli A 2007 Menstrual cycle-dependent changes of toll-like receptors in endometrium. Human Reproduction 22 586-593.

Ananth CV \& Vintzileos AM 2006 Epidemiology of preterm birth and its clinical subtypes. Journal of Maternal Fetal and Neonatal Medicine 19 773-782.

Andersen JM, Al-Khairy D \& Ingalls RR 2006 Innate immunity at the mucosal surface: role of toll-like receptor 3 and toll-like receptor 9 in cervical epithelial cell responses to microbial pathogens. Biology of Reproduction 74 824-831.

Andersen-Nissen E, Hawn TR, Smith KD, Nachman A, Lampano AE, Uematsu S, Akira S \& Aderem A 2007 Cutting edge: Tlr5 - / - mice are more susceptible to Escherichia coli urinary tract infection. Journal of Immunology 178 4717-4720.

Angelov N, Moutsopoulos N, Jeong MJ, Nares S, Ashcroft G \& Wahl SM 2004 Aberrant mucosal wound repair in the absence of secretory leukocyte protease inhibitor. Thrombosis and Haemostasis 92 288-297. 
Ashcroft GS, Lei K, Jin W, Longenecker G, Kulkarni AB, Greenwell-Wild T, Hale-Donze H, McGrady G, Song XY \& Wahl SM 2000 Secretory leukocyte protease inhibitor mediates non-redundant functions necessary for normal wound healing. Nature Medicine 6 1147-1153.

Beagley KW \& Timms P 2000 Chlamydia trachomatis infection: incidence, health costs and prospects for vaccine development. Journal of Reproductive Immunology 48 47-68.

Beijar EC, Mallard C \& Powell TL 2006 Expression and subcellular localization of TLR-4 in term and first trimester human placenta. Placenta 27 322-326.

van Bergen BH, Andriessen MP, Spruijt KI, van de Kerkhof PC \& Schalkwijk J 1996 Expression of SKALP/elafin during wound healing in human skin. Archives of Dermatological Research 288 458-462.

Buhimschi IA, Jabr M, Buhimschi CS, Petkova AP, Weiner CP \& Saed GM 2004 The novel antimicrobial peptide beta3-defensin is produced by the amnion: a possible role of the fetal membranes in innate immunity of the amniotic cavity. American Journal of Obstetrics and Gynecology 191 1678-1687.

Bulmer JN, Pace D \& Ritson A 1988 Immunoregulatory cells in human decidua: morphology, immunohistochemistry and function. Reproduction, Nutrition, Development 28 1599-1613.

Bulut $Y$, Faure E, Thomas L, Karahashi $H$, Michelsen KS, Equils $O$, Morrison SG, Morrison RP \& Arditi M 2002 Chlamydial heat shock protein 60 activates macrophages and endothelial cells through toll-like receptor 4 and MD2 in a MyD88-dependent pathway. Journal of Immunology 168 1435-1440.

Clark DA, Vince G, Flanders KC, Hirte H \& Starkey P 1994 CD56+ lymphoid cells in human first trimester pregnancy decidua as a source of novel transforming growth factor-beta 2-related immunosuppressive factors. Human Reproduction 9 2270-2277.

Costello MJ, Joyce SK \& Abrahams VM 2007 NOD protein expression and function in first trimester trophoblast cells. American Journal of Reproductive Immunology 57 67-80.

Dalgetty DM, Sallenave JM, Critchley HO, Williams AR, Tham WY, King AE \& Horne AW 2008 Altered secretory leukocyte protease inhibitor expression in the uterine decidua of tubal compared with intrauterine pregnancy. Human Reproduction [in press].

Dallegri F \& Ottonello L 1997 Tissue injury in neutrophilic inflammation. Inflammation Research 46 382-391.

Darville T, $\mathrm{O}^{\prime}$ Neill JM, Andrews CW Jr, Nagarajan UM, Stahl L \& Ojcius DM 2003 Toll-like receptor-2, but not toll-like receptor-4, is essential for development of oviduct pathology in chlamydial genital tract infection. Journal of Immunology 171 6187-6197.

Denison FC, Kelly RW, Calder AA \& Riley SC 1999 Secretory leukocyte protease inhibitor concentration increases in amniotic fluid with the onset of labour in women: characterization of sites of release within the uterus. Journal of Endocrinology 161 299-306.

Draper DL, Landers DV, Krohn MA, Hillier SL, Wiesenfeld HC \& Heine RP 2000 Levels of vaginal secretory leukocyte protease inhibitor are decreased in women with lower reproductive tract infections. American Journal of Obstetrics and Gynecology 183 1243-1248.

Equils O, Lu D, Gatter M, Witkin SS, Bertolotto C, Arditi M, McGregor JA, Simmons CF \& Hobel CJ 2006 Chlamydia heat shock protein 60 induces trophoblast apoptosis through TLR4. Journal of Immunology 177 1257-1263.

Eriksson M, Meadows SK, Basu S, Mselle TF, Wira CR \& Sentman CL 2006 TLRs mediate IFN-gamma production by human uterine NK cells in endometrium. Journal of Immunology 176 6219-6224.

Fahey JV \& Wira CR 2002 Effect of menstrual status on antibacterial activity and secretory leukocyte protease inhibitor production by human uterine epithelial cells in culture. Journal of Infectious Disease $\mathbf{1 8 5}$ 1606-1613.

Faro S 1991 Chlamydia trachomatis: female pelvic infection. American Journal of Obstetrics and Gynecology 164 1767-1770.

Farquhar CM 2005 Ectopic pregnancy. Lancet 366 583-591.

Fichorova RN \& Anderson DJ 1999 Differential expression of immunobiological mediators by immortalized human cervical and vaginal epithelial cells. Biology of Reproduction 60 508-514.

Fichorova RN, Cronin AO, Lien E, Anderson DJ \& Ingalls RR 2002 Response to Neisseria gonorrhoeae by cervicovaginal epithelial cells occurs in the absence of toll-like receptor 4-mediated signaling. Journal of Immunology 168 2424-2432.
Fleming DC, King AE, Williams ARW, Critchley HOD \& Kelly RW 2003 Hormonal contraception can suppress natural antimicrobial gene transcription in human endometrium. Fertility and Sterility 79 856-863.

Ganz T 2004 Antimicrobial polypeptides. Journal of Leukocyte Biology 75 $34-38$.

Ghosh M, Schaefer TM, Fahey JV, Wright JA \& Wira CR 2008 Antiviral responses of human Fallopian tube epithelial cells to toll-like receptor 3 agonist poly(I:C). Fertility and Sterility [in press]. doi: 10.1016/j.fertnstert.2007.05.023.

den Hartog JE, Ouburg S, Land JA, Lyons JM, Ito JI, Pena AS \& Morre SA 2006 Do host genetic traits in the bacterial sensing system play a role in the development of Chlamydia trachomatis-associated tubal pathology in subfertile women? BMC Infectious Diseases 6122.

Hein M, Valore EV, Helmig RB, Uldbjerg N \& Ganz T 2002 Antimicrobial factors in the cervical mucus plug. American Journal of Obstetrics and Gynecology 187 137-144.

Helmig R, Uldbjerg N \& Ohlsson K 1995 Secretory leukocyte protease inhibitor in the cervical mucus and in the fetal membranes. European Journal of Obstetrics Gynecology and Reproductive Biology 59 95-101.

Helmig BR, Romero R, Espinoza J, Chaiworapongsa T, Bujold E, Gomez R, Ohlsson K \& Uldbjerg N 2002 Neutrophil elastase and secretory leukocyte protease inhibitor in prelabor rupture of membranes, parturition and intra-amniotic infection. Journal of Maternal Fetal and Neonatal Medicine 12 237-246.

Henriksen PA, Hitt M, Xing Z, Wang J, Haslett C, Riemersma RA, Webb DJ, Kotelevtsev YV \& Sallenave JM 2004 Adenoviral gene delivery of elafin and secretory leukocyte protease inhibitor attenuates NF-kappa B-dependent inflammatory responses of human endothelial cells and macrophages to atherogenic stimuli. Journal of Immunology $\mathbf{1 7 2}$ 4535-4544.

Hirata T, Osuga Y, Hirota Y, Koga K, Yoshino O, Harada M, Morimoto C, Yano T, Nishii O, Tsutsumi O et al. 2005 Evidence for the presence of toll-like receptor 4 system in the human endometrium. Journal of Clinical Endocrinology and Metabolism 90 548-556.

Hirata T, Osuga Y, Hamasaki K, Hirota Y, Nose E, Morimoto C, Harada M, Takemura Y, Koga K, Yoshino O et al. 2007 Expression of toll-like receptors $2,3,4$, and 9 genes in the human endometrium during the menstrual cycle. Journal of Reproductive Immunology 74 53-60.

Holmlund U, Cebers G, Dahlfors AR, Sandstedt B, Bremme K, Ekstrom ES \& Scheynius A 2002 Expression and regulation of the pattern recognition receptors toll-like receptor- 2 and toll-like receptor- 4 in the human placenta. Immunology 107 145-151.

Hunt JS 1994 Immunologically relevant cells in the uterus. Biology of Reproduction 50 461-466.

Ilievski V, Lu SJ \& Hirsch E 2007 Activation of toll-like receptors 2 or 3 and preterm delivery in the mouse. Reproductive Sciences 14 315-320.

Itoh H, Nasu K, Nishida M, Matsumoto H, Yuge A \& Narahara H 2006 Human oviductal stromal fibroblasts, but not oviductal epithelial cells, express toll-like receptor 4: the site-specific mucosal immunity of the human fallopian tube against bacterial infection. American Journal of Reproductive Immunology 56 91-101.

Janeway CA Jr \& Medzhitov R 2002 Innate immune recognition. Annual Review of Immunology 20 197-216.

Jin FY, Nathan C, Radzioch D \& Ding A 1997 Secretory leukocyte protease inhibitor: a macrophage product induced by and antagonistic to bacterial lipopolysaccharide. Cell 88 417-426.

Kanzler H, Barrat FJ, Hessel EM \& Coffman RL 2007 Therapeutic targeting of innate immunity with toll-like receptor agonists and antagonists. Nature Medicine 13 552-559.

Kim YM, Romero R, Chaiworapongsa T, Kim GJ, Kim MR, Kuivaniemi H, Tromp G, Espinoza J, Bujold E \& Abrahams VM 2004 Toll-like receptor-2 and -4 in the chorioamniotic membranes in spontaneous labor at term and in preterm parturition that are associated with chorioamnionitis. American Journal of Obstetrics and Gynecology 191 1346-1355.

King A \& Loke YW 1991 On the nature and function of human uterine granular lymphocytes. Immunology Today 12 432-435.

King AE, Critchley HOD \& Kelly RW 2000 Presence of secretory leukocyte protease inhibitor in human endometrium and first trimester decidua suggests an antibacterial protective role. Molecular Human Reproduction 6 191-196.

King AE, Critchley HO \& Kelly RW 2003a Innate immune defences in the human endometrium. Reproduction Biology and Endocrinology 1116. 
King AE, Fleming DC, Critchley HOD \& Kelly RW 2003b Differential expression of the natural antimicrobials, beta-defensins 3 and 4 , in human endometrium. Journal of Reproductive Immunology 59 1-16.

King AE, Critchley HOD, Sallenave JM \& Kelly RW 2003 c Elafin in human endometrium: an anti-protease and anti-microbial molecule expressed during menstruation. Journal of Clinical Endocrinology and Metabolism 88 4426-4431.

King AE, Paltoo A, Kelly RW, Sallenave JM, Bocking AD \& Challis JR 2007 Expression of natural antimicrobials by human placenta and fetal membranes. Placenta 28 161-169.

Klotman ME \& Chang TL 2006 Defensins in innate antiviral immunity. Nature Reviews Immunology 6 447-456.

Krediet TG, Wiertsema SP, Vossers MJ, Hoeks SB, Fleer A, Ruven HJ \& Rijkers GT 2007 Toll-like receptor 2 polymorphism is associated with preterm birth. Pediatric Research 62 474-476.

Krikun G, Lockwood CJ, Abrahams VM, Mor G, Paidas M \& Guller S 2007 Expression of toll-like receptors in the human decidua. Histology and Histopathology 22 847-854.

Kumazaki K, Nakayama M, Yanagihara I, Suehara N \& Wada Y 2004 Immunohistochemical distribution of toll-like receptor 4 in term and preterm human placentas from normal and complicated pregnancy including chorioamnionitis. Human Pathology 35 47-54.

Lentsch AB, Jordan JA, Czermak BJ, Diehl KM, Younkin EM, Sarma V \& Ward PA 1999 Inhibition of NF-kappaB activation and augmentation of IkappaBbeta by secretory leukocyte protease inhibitor during lung inflammation. American Journal of Pathology 154 239-247.

Lesmeister MJ, Jorgenson RL, Young SL \& Misfeldt ML 2005 17Betaestradiol suppresses TLR3-induced cytokine and chemokine production in endometrial epithelial cells. Reproduction Biology and Endocrinology 374

Lorenz E, Hallman M, Marttila R, Haataja R \& Schwartz DA 2002 Association between the Asp299Gly polymorphisms in the toll-like receptor 4 and premature births in the Finnish population. Pediatric Research 52 373-376.

Ma Y, Krikun G, Abrahams VM, Mor G \& Guller S 2007 Cell type-specific expression and function of toll-like receptors 2 and 4 in human placenta: implications in fetal infection. Placenta 28 1024-1031.

Mardh PA 2004 Tubal factor infertility, with special regard to chlamydial salpingitis. Current Opinion in Infectious Diseases 17 49-52.

Marx L, Arck P, Kapp M, Kieslich C \& Dietl J 1999 Leukocyte populations, hormone receptors and apoptosis in eutopic and ectopic first trimester human pregnancies. Human Reproduction 14 1111-1117.

Mitsuhashi H, Asano S, Nonaka T, Hamamura I, Masuda K \& Kiyoki M 1996 Administration of truncated secretory leukoprotease inhibitor ameliorates bleomycin-induced pulmonary fibrosis in hamsters. American Journal of Respiratory and Critical Care Medicine 153 369-374.

Moriyama A, Shimoya K, Ogata I, Kimura T, Nakamura T, Wada H, Ohashi K, Azuma C, Saji F \& Murata Y 1999 Secretory leukocyte protease inhibitor (SLPI) concentrations in cervical mucus of women with normal menstrual cycle. Molecular Human Reproduction 5 656-661.

Morre SA, Lyons JM \& Ito JI Jr 2000 Murine models of Chlamydia trachomatis genital tract infection: use of mouse pneumonitis strain versus human strains. Infection and Immunity 68 7209-7211.

Narvekar N, Lakha F, Critchley HO, Glasier AF, Williams AR, Leminen R, Heikinheimo O, Kelly RW \& Baird DT 2007 Changes in vaginal morphology, steroid receptor and natural antimicrobial content following treatment with low-dose mifepristone. Contraception $\mathbf{7 5}$ 271-280.

Nasu K, Itoh H, Yuge A, Nishida M \& Narahara H 2007 Human oviductal epithelial cells express toll-like receptor 3 and respond to doublestranded RNA: fallopian tube-specific mucosal immunity against viral infection. Human Reproduction 22 356-361.

O'Connell CM, Ionova IA, Quayle AJ, Visintin A \& Ingalls RR 2006 Localization of TLR2 and MyD88 to Chlamydia trachomatis inclusions. Evidence for signaling by intracellular TLR2 during infection with an obligate intracellular pathogen. Journal of Biological Chemistry 281 1652-1659.

Odland JO, Anestad G, Rasmussen S, Lundgren R \& Dalaker K 1993 Ectopic pregnancy and chlamydial serology. International Journal of Gynaecology and Obstetrics 43 271-275.
Ohta K, Nakajima T, Cheah AY, Zaidi SH, Kaviani N, Dawood F, You XM, Liu P, Husain M \& Rabinovitch M 2004 Elafin-overexpressing mice have improved cardiac function after myocardial infarction. American Journal of Physiology. Heart and Circulatory Physiology 287 286-292.

Ota Y, Shimoya K, Zhang Q, Moriyama A, Chin R, Tenma K, Kimura T, Koyama M, Azuma C \& Murata Y 2002 The expression of secretory leukocyte protease inhibitor (SLP1) in the fallopian tube: SLP1 protects the acrosome reaction of sperm from inhibitory effects of elastase. Human Reproduction 17 2517-2522.

Pfundt $R$, van Ruissen $F$, van Vlijmen-Willems IM, Alkemade HA, Zeeuwen PL, Jap PH, Dijkman H, Fransen J, Croes H, van Erp PE et al. 1996 Constitutive and inducible expression of SKALP/elafin provides anti-elastase defense in human epithelia. Journal of Clinical Investigation 98 1389-1399.

Pioli PA, Amiel E, Schaefer TM, Connolly JE, Wira CR \& Guyre PM 2004 Differential expression of toll-like receptors 2 and 4 in tissues of the human female reproductive tract. Infection and Immunity $\mathbf{7 2}$ 5799-5806.

Quayle AJ 2002 The innate and early immune response to pathogen challenge in the female genital tract and the pivotal role of epithelial cells. Journal of Reproductive Immunology 57 61-79.

Quayle AJ, Porter EM, Nussbaum AA, Wang YM, Brabec C, Yip KP \& Mok SC 1998 Gene expression, immunolocalization, and secretion of human defensin-5 in human female reproductive tract. American Journal of Pathology 152 1247-1258.

Rindsjo E, Holmlund U, Sverremark-Ekstrom E, Papadogiannakis N \& Scheynius A 2007 Toll-like receptor-2 expression in normal and pathologic human placenta. Human Pathology 38 468-473.

Romero R, Espinoza J, Goncalves LF, Kusanovic JP, Friel L \& Hassan S 2007 The role of inflammation and infection in preterm birth. Seminars in Reproductive Medicine 25 21-39.

Sallenave JM 2000 The role of secretory leukocyte proteinase inhibitor and elafin (elastase-specific inhibitor/skin-derived antileukoprotease) as alarm antiproteinases in inflammatory lung disease. Respiratory Research 1 87-92.

Sallenave JM \& Ryle AP 1991 Purification and characterization of elastasespecific inhibitor. Sequence homology with mucus proteinase inhibitor. Biological Chemistry Hoppe-Seyler 372 13-21.

Sallenave JM, Shulmann J, Crossley J, Jordana M \& Gauldie J 1994 Regulation of secretory leukocyte proteinase inhibitor (SLPI) and elastase-specific inhibitor (ESI/elafin) in human airway epithelial cells by cytokines and neutrophilic enzymes. American Journal of Respiratory Cell and Molecular Biology 11 733-741.

Sallenave JM, Cunningham GA, James RM, McLachlan G \& Hasslet C 2003 Regulation of pulmonary and systemic bacterial lipopolysaccharide responses in transgenic mice expressing human elafin. Infection and Immunity 71 3766-3774.

Sano C, Shimizu T \& Tomioka H 2003 Effects of secretory leukocyte protease inhibitor on the tumor necrosis factor-alpha production and NF-kappaB activation of lipopolysaccharide-stimulated macrophages. Cytokine 21 38-42.

Schaefer TM, Desouza K, Fahey JV, Beagley KW \& Wira CR 2004 Toll-like receptor (TLR) expression and TLR-mediated cytokine/chemokine production by human uterine epithelial cells. Immunology 112 428-436.

Schaefer TM, Fahey JV, Wright JA \& Wira CR 2005 Innate immunity in the human female reproductive tract: antiviral response of uterine epithelial cells to the TLR3 agonist poly(I:C). Journal of Immunology $\mathbf{1 7 4}$ 992-1002.

Schalkwijk J, Wiedow O \& Hirose S 1999 The trappin gene family: proteins defined by an $\mathrm{N}$-terminal transglutaminase substrate domain and a C-terminal four-disulphide core. Biochemical Journal 340 (Pt 3) 569-577.

Schmid M, Fellermann K, Fritz P, Wiedow O, Stange EF \& Wehkamp J 2007 Attenuated induction of epithelial and leukocyte serine antiproteases elafin and secretory leukocyte protease inhibitor in Crohn's disease. Journal of Leukocyte Biology 4 907-915.

Simpson AJ, Maxwell AI, Govan JR, Haslett C \& Sallenave JM 1999 Elafin (elastase-specific inhibitor) has anti-microbial activity against grampositive and gram-negative respiratory pathogens. FEBS Letters $\mathbf{4 5 2}$ 309-313.

Sonnex C 1998 Influence of ovarian hormones on urogenital infection. Sexually Transmitted Infections $\mathbf{7 4}$ 11-19. 
Stock RJ 1991 Tubal pregnancy. Associated histopathology. Obstetrics and Gynecology Clinics of North America 18 73-94.

Stock SJ, Kelly RW, Riley SC \& Calder AA 2007 Natural antimicrobial production by the amnion. American Journal of Obstetrics and Gynecology 255 e1-e6.

Sugawara I, Yamada H, Li C, Mizuno S, Takeuchi O \& Akira S 2003 Mycobacterial infection in TLR2 and TLR6 knockout mice. Microbiology and Immunology 47 327-336.

Sulz L, Valenzuela JP, Salvatierra AM, Ortiz ME \& Croxatto HB 1998 The expression of alpha(v) and beta3 integrin subunits in the normal human Fallopian tube epithelium suggests the occurrence of a tubal implantation window. Human Reproduction 13 2916-2920.

Svinarich DM, Wolf NA, Gomez R, Gonik B \& Romero R 1997 Detection of human defensin 5 in reproductive tissues. American Journal of Obstetrics and Gynecology 176 470-475.

Taggart CC, Cryan SA, Weldon S, Gibbons A, Greene CM, Kelly E, Low TB, O'neill SJ \& McElvaney NG 2005 Secretory leucoprotease inhibitor binds to NF-kappaB binding sites in monocytes and inhibits p65 binding. Journal of Experimental Medicine 202 1659-1668.

Tay JI, Moore J \& Walker JJ 2000 Ectopic pregnancy. BMJ 320 916-919.

Thompson RC \& Ohlsson K 1986 Isolation, properties, and complete amino acid sequence of human secretory leukocyte protease inhibitor, a potent inhibitor of leukocyte elastase. PNAS 83 6692-6696.

Tosi MF 2005 Innate immune responses to infection. Journal of Allergy and Clinical Immunology 116 241-249.

Tromp G, Kuivaniemi H, Romero R, Chaiworapongsa T, Kim YM, Kim MR, Maymon E \& Edwin S 2004 Genome-wide expression profiling of fetal membranes reveals a deficient expression of proteinase inhibitor 3 in premature rupture of membranes. American Journal of Obstetrics and Gynecology 191 1331-1338.

Valore EV, Park CH, Quayle AJ, Wiles KR, McCray PB Jr \& Ganz T 1998 Human beta-defensin-1: an antimicrobial peptide of urogenital tissues. Journal of Clinical Investigation 101 1633-1642.

Valore EV, Wiley DJ \& Ganz T 2006 Reversible deficiency of antimicrobial polypeptides in bacterial vaginosis. Infection and Immunity $\mathbf{7 4}$ 5693-5702.

Wang H \& Hirsch E 2003 Bacterially-induced preterm labor and regulation of prostaglandin-metabolizing enzyme expression in mice: the role of toll-like receptor 4. Biology of Reproduction 69 1957-1963.

Wang X, Li X, Xu L, Zhan Y, Yaish-Ohad S, Erhardt JA, Barone FC \& Feuerstein GZ 2003 Up-regulation of secretory leukocyte protease inhibitor (SLPI) in the brain after ischemic stroke: adenoviral expression of SLPI protects brain from ischemic injury. Molecular Pharmacology 64 833-840.
Welter-Stahl L, Ojcius DM, Viala J, Girardin S, Liu W, Delarbre C, Philpott D, Kelly KA \& Darville T 2006 Stimulation of the cytosolic receptor for peptidoglycan, Nod1, by infection with Chlamydia trachomatis or Chlamydia muridarum. Cellular Microbiology 8 1047-1057.

Wiedow O, Luademann J \& Utecht B 1991 Elafin is a potent inhibitor of proteinase 3. Biochemical and Biophysical Research Communications 174 6-10.

Wiesenfeld HC, Hillier SL, Krohn MA, Amortegui AJ, Heine RP, Landers DV \& Sweet RL 2002 Lower genital tract infection and endometritis: insight into subclinical pelvic inflammatory disease. Obstetrics and Gynecology $100456-463$.

Wingens M, van Bergen BH, Hiemstra PS, Meis JF, van Vlijmen-Willems IM, Zeeuwen PL, Mulder J, Kramps HA, van Ruissen F \& Schalkwijk J 1998 Induction of SLPI (ALP/HUSI-I) in epidermal keratinocytes. Journal of Investigative Dermatology 111 996-1002.

Wira CR, Fahey JV, Sentman CL, Pioli PA \& Shen L 2005 Innate and adaptive immunity in female genital tract: cellular responses and interactions. Immunological Reviews 206 306-335.

Zarember KA \& Godowski PJ 2002 Tissue expression of human toll-like receptors and differential regulation of toll-like receptor mRNAs in leukocytes in response to microbes, their products, and cytokines. Journal of Immunology 168 554-561.

Zhang Y, DeWitt DL, McNeely TB, Wahl SM \& Wahl LM 1997 Secretory leukocyte protease inhibitor suppresses the production of monocyte prostaglandin $\mathrm{H}$ synthase-2, prostaglandin E2, and matrix metalloproteinases. Journal of Clinical Investigation 99 894-900.

Zhang Q, Shimoya K, Moriyama A, Yamanaka K, Nakajima A, Nobunaga T, Koyama M, Azuma C \& Murata Y 2001 Production of secretory leukocyte protease inhibitor by human amniotic membranes and regulation of its concentration in amniotic fluid. Molecular Human Reproduction 7 573-579.

Zhang J, Wei H, Wu D \& Tian Z 2007 Toll-like receptor 3 agonist induces impairment of uterine vascular remodeling and fetal losses in CBA x DBA/2 mice. Journal of Reproductive Immunology 74 61-67.

Received 17 December 2007

First decision 18 January 2008

Revised manuscript received 26 February 2008

Accepted 14 March 2008 